\title{
MEDIA PEMBELAJARAN INTERAKTIF SIFAT WUDHU, TAYAMMUM, DAN SHALAT NABI SHALLALLAHU 'ALAIHI WA SALLAM UNTUK ANAK-ANAK
}

\author{
Taufik Rachman ${ }^{1}$, Ayatullah Firmansyah ${ }^{2}$ \\ 1,2 Program Studi Teknik Informatika, STT Stikma Internasional Malang \\ ktopik@gmail.com
}

\begin{abstract}
ABSTRAK
Media pembelajaran interaktif adalah suatu sarana pengajaran yang menyajikan materi yang dapat memudahkan pengguna dalam menerima materi dimana pengguna tidak hanya melihat (visual) atau mendengar (audio) materi yang disampaikan, tetapi juga memberikan respon aktif terhadap materi yang disampaikan. Dengan menggunakan media yang bersifat multimedia tersebut segala informasi yang akan disampaikan akan lebih menarik dan tidak membosankan.

Pada umumnya kegiatan belajar mengajar tentang materi wudhu, tayammmum dan shalat masih menggunakan media verbal dan buku yang cenderung bersifat pasif bagi peserta didik. Sehingga suasana belajar akan menjadi membosankan yang berdampak proses belajar mengajar berjalan tidak efektif. Dengan memanfaatkan media pembelajaran interkatif tersebut maka materi wudhu, tayammmum dan shalat yang akan dipelajari akan mudah tersampaikan dan mempermudah peserta didik khususnya anak - anak untuk lebih memahami materi yang disampaikan.
\end{abstract}

\section{Keyword : Media Pembelajaan Interaktif; Sifat Wudhu; Tayammum; Shalat Nabi}

\section{PENDAHULUAN}

Setiap muslim memiliki kewajiban utama untuk mendirikan shalat lima waktu. Shalat merupakan tiang agama dan amalan yang akan dihisab pertama kali pada hari kiamat adalah amalan shalat. Ibadah shalat tidak akan diterima jika tidak bersuci terlebih dahulu, yaitu dengan cara berwudhu atau tayammum apabila tidak menemui air yang dapat digunakan untuk bewudhu. Semua ibadah tersebut merupakan satu rangkaian amalan yang sangat penting untuk dipelajari setiap orang yang mengaku beragama Islam. Pengajaran dan penerapan ilmu tersebut haruslah benar sesuai dengan tuntunan Rasulullah Shallallahu 'alaihi Wa Sallam. Untuk mempelajarinya dan membiasakannya haruslah dimulai sejak masa kanak - kanak.

Dahulu sebelum teknologi berkembang pesat seperti sekarang ini, proses pengajaran yang dilakukan masih menggunakan metode komunikasi manual antara guru dan murid dengan menggunakan bahasa verbal dan fisik sebagai praktek untuk visualisasi secara langsung tentang tatacara wudhu, tayammum, dan shalat tersebut. Dengan metode seperti itu, kebanyakan anak - anak akan merasa bosan dan susah menangkap makna yang disampaikan karena dianggap kurang menarik serta dibutuhkannya tempat dan waktu tertentu, yaitu saat mengaji kepada guru di sekolah dan udztad di masjid. Ketergantungan kepada guru atau udztad untuk membimbing tersebut menjadi kendala utama jika menggunakan metode ini. Selain itu, metode lain yang digunakan adalah menggunakan buku dan video tentang wudhu, tayammum, dan shalat. Dengan metode ini orang tua masih bingung untuk memberikan arahan atau pengajaran kepada anak anak mereka dan metode tersebut kurang menarik jika diamplikasikan pada anak - anak zaman sekarang dan bersifat kurang interaktif. Anak - anak cenderung pasif dalam mengikuti apa yang disampaikan pada materi tersebut. Kendala lain dengan menggunakan media buku adalah di negara Indonesia masih banyak anak - anak bahkan orang tua yang memiliki sifat malas untuk membaca sehingga metode ini tidak begitu efektif sebagai media pembelajaran. Dari semua masalah tersebut dampak yang terjadi adalah akan terhambatnya proses pembelajaran terutama di usia anak - anak yang mengakibatkan adanya kesalahan dalam gerakan ataupun tatacaranya dalam melaksanakan praktek wudhu, tayammum, dan shalat.

Berawal dari masalah tersebut dan mengetahui bahwa pentingnya ilmu tentang wudhu, tayammum dan shalat terutama di usia anak - anak, maka kami mencoba menyajikan bentuk media pembelajaran interaktif sifat wudhu, tayammum, dan shalat Nabi Shallallahu 'alaihi Wa Sallam yang dikhususkan untuk anak - anak dengan menggunakan multimedia yang menggabungkan berbagai unsur media seperti suara, video animasi, teks, dan gambar yang materinya disusun berdasarkan hadits - hadits shahih seperti yang telah diajarkan Nabi Shallallahu 'alaihi Wa Sallam. Animasi dan grafis yang menarik merupakan kunci utama dalam pembuatan media pembelajaran ini, yang nantinya berguna untuk menjelaskan materi serta memvisualisasikan praktek tentang wudhu, tayammum, dan shalat agar anak - anak tidak bosan dalam mempelajari materinya. Dengan memanfaatkan teknologi informasi seperti media pembelajaran interaktif sebagai sarana pembelajaran, maka proses belajar mengajar akan menjadi lebih menarik dan bermanfaat sebagai media alternatif bagi masyarakat untuk mempermudah dalam proses belajar dan mengajarkan materi tentang wudhu, tayammum, dan shalat yang sesuai dengan tuntunan Rasulullah Shallallahu 'alaihi Wa Sallam kepada anak - anak mereka. Dan juga anak - anak tersebut mudah

Copyright (c) 2021 Jurnal Mnemonic 
mempelajari materi yang ada dan semakin tertarik untuk belajar materi tersebut

\section{TINJAUAN PUSTAKA}

\subsection{Media Pembelajaran Interaktif}

Media berasal dari bahasa latin yang secara harfiah mempunyai arti perantara atau pengantar. Dalam ilmu komunikasi, media bisa diartikan sebagai saluran, sarana penghubung, dan alat - alat komunikasi.

Pembelajaran adalah proses interaksi peserta didik dengan pendidik dan sumber belajar pada suatu lingkungan belajar. Pembelajaran merupakan bantuan yang diberikan pendidik agar dapat terjadi proses perolehan ilmu dan pengetahuan, penguasaan kemahiran dan tabiat, serta pembentukan sikap dan kepercayaan pada peserta didik. Dengan kata lain, pembelajaran adalah proses untuk membantu peserta didik agar dapat belajar dengan baik.

Interaktif adalah tindakan yang bersifat saling melakukan aksi. Bisa dikatakan terdapat dua objek yang saling berhubungan atau berinteraksi secara aktif. Dapat dicontohkan antara komputer dengan manusia.

Mengacu dari definisi ketiga kata tersebut Media Pembelajaran Interaktif dapat diartikan sebagai suatu sarana pengajaran yang menyajikan materi yang dapat memudahkan pengguna dalam menerima materi dimana pengguna tidak hanya melihat (visual) atau mendengar (audio) materi yang disampaikan, tetapi juga memberikan respon aktif terhadap materi yang disampaikan. Materi yang disampaikan pada Media Pembelajaran Interaktif tidak hanya bersifat gambar atau visual saja melaikan menggabungkannya dengan audio (termasuk animasi) karena memiliki unsur audio dan visual media ini dapat dikategorikan sebagai multimedia.

\subsection{Multimedia}

Pengertian multimedia secara umum adalah gabungan dari berbagai media informasi dengan menggunakan fasilitas komputer. Multimedia merupakan suatu konsep dan teknologi baru dalam bidang teknologi informasi. Dimana teks, gambar, suara, animasi, video disatukan dalam komputer untuk disimpan, diproses dan disajikan untuk menyampaikan pesan kepada publik.

Pemanfaatan multimedia sangatlah banyak diantaranya sebagai media pembelajaran, game, film, medis, militer, bisnis, desain, arsitektur, olahraga, hobi, dan iklan/promosi. Yang menjadikan multimedia disebut interaktif adalah dimana pengguna mendapatkan keleluasaan dalam mengontrol multimedia tersebut. Jika berbicara multimedia pembelajaran yang interaktif harus memiliki lebih dari satu media yang konvergen misalnya menggabungkan unsur audio dan visual, memiliki kemampuan untuk mengakomodasi respon pengguna, dan mempermudah pemahaman materi pembelajaran yang lengkap dan menarik sehingga pengguna bisa menggunakannya tanpa bimbingan orang lain.

\subsection{Wudhu}

Wudhu adalah ibadah yang sangat agung yang merupakan syarat sah ibadah shalat seseorang karena wudhu merupakan salah satu cara bersuci dari hadats kecil yang dilakukan sebelum mengerjakan shalat. Seperti yang diriwayatkan oleh Imam Bukhari, Rasulullah Shallallahu 'alaihi Wa Sallam bersabda yang artinya "Tidaklah diterima shalat seseorang apabila ia dalam keadaan berhadats (kotor) sehingga ia berwudhu". Dalil dalam Al Qur'an yang membahas tentang wudhu ini terdapat pada surah al-Maidah ayat 6 yang artinya "Hai orang - orang yang beriman, apabila kamu hendak mengerjakan shalat, maka basuhlah mukamu dan tanganmu sampai dengan siku, dan sapulah kepalamu dan (basuh) kakimu sampai dengan kedua mata kaki ...".

\subsection{Tayammum}

Tayammum secara bahasa diartikan maksud. Sedangkan secara istilah dalam syari'at menurut Syaikh Muhammad bin Sholeh Al 'Utsaimin rahimahullah adalah sebuah peribadatan kepada Allah berupa mengusap wajah dan kedua tangan dengan menggunakan sho'id yang bersih. Sho'id adalah seluruh permukaan bumi yang dapat digunakan untuk bertayammum baik yang terdapat tanah di atasnya ataupun tidak.

Tayammum disyari'atkan dalam islam berdasarkan dalil Al Qur'an dan As Sunnah. Adapun dalil dari Al Qur'an adalah firman Allah Azza wa Jalla dalam surah al-Maidah ayat 6 sebagai lanjutan penjelasan tentang wudhu “... Dan jika kamu sakit atau dalam perjalanan atau kembali dari tempat buang air atau berhubungan badan dengan perempuan, lalu kamu tidak memperoleh air, maka bertayammumlah dengan permukaan bumi yang baik (bersih); sapulah mukamu dan tanganmu dengan tanah itu"

Adapun dalil dari As Sunnah adalah sabda Rasulullah Shallallahu 'alaihi Wa Sallam dari sahabat Hudzaifah Ibnul Yaman radhiyallahu 'anhu, "Dijadikan bagi kami (ummat Nabi Muhammad Shallallahu 'alaihi Wa Sallam) permukaan bumi sebagai thohur / sesuatu yang digunakan untuk besuci (tayammum) jika kami tidak menjumpai air". (HR. Muslim)

\subsection{Pengertian Shalat}

Jika merujuk ke rukun Islam maka shalat merupakan rukun Islam yang kedua. Shalat merupakan tiang agama yang tidak akan tegak tanpanya. Shalat adalah ibadah pertama yang Allah wajibkan. Karena itu shalat hukumnya wajib bagi seluruh umat Islam dan jika ditinggalkan maka akan berdosa. Shalat adalah amal pertama yang 
diperhitungkan di hari kiamat. Shalat adalah wasiat terakhir Rasulullah Shallallahu 'alaihi Wa Sallam kepada umatnya ketika Beliau hendak meninggal dunia.

Maka dari itu shalat dianjurkan untuk diperintahkan kepada anak-anak yang sudah berumur tujuh tahun. Dan dipukul jika tidak mengerjakannya setelah berusia sepuluh tahun. Ini agar shalat menjadi kebiasaannya. Seperti dalam hadits, "Perintahkan anakmu shalat ketika berusia tujuh tahun, dan pukullah ia jika berusia sepuluh tahun, pisahkan tempat tidur mereka." (HR. Ahmad, Abu Daud, dan Hakim, yang mengatakan hadits ini shahih sesuai dengan persyaratan Imam Muslim).

\section{METODE PENELITIAN}

Dalam merancang isi dari media pembelajaran sangat erat hubungannya dengan materi apa saja yang nantinya akan dimasukkan dalam sistem dan alur sistem yang berjalan pada aplikasi tersebut. Yang pertama kali dilakukan adalah penyusunan materi - materi yang akan dimasukkan dengan cara studi pustaka tentang materi tayammum, wudhu dan shalat tersebut. Dari materi yang telah tersusun maka akan diatur sedemikan rupa menjadi dalam satu alur bab sehingga memudahkan pengguna untuk memilih materi yang akan dipelajari.

Dari proses tersebut maka akan diperoleh desain sistem yang diatur menjadi struktur navigasi. Struktur navigasi merupakan alat bantu untuk merancang aliran aplikasi multimedia. Adapun struktur navigasi dalam pembuatan media pembelajaran interaktif ini sebagai berikut:

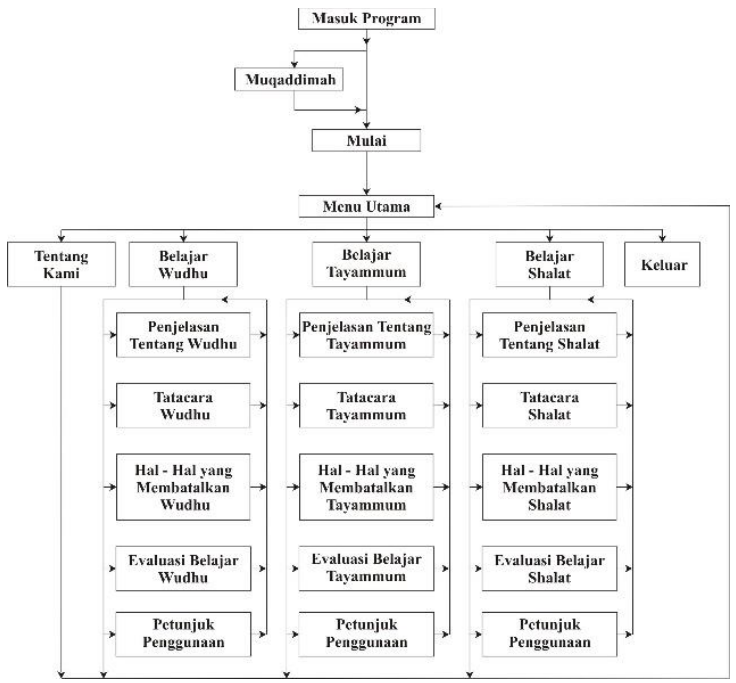

Gambar 1 Struktur Navigasi Sistem

Struktur Navigasi ini menjelaskan alur dari aplikasi Media Pembelajaran Interaktif Sifat Wudhu, Tayammum, Dan Shalat Nabi Shallallahu 'alaihi Wa Sallam Untuk Anak - Anak. Pada struktur navigasi tersebut dijelaskan:

1. Hal pertama yang dilakukan user masuk pada program, terdapat pilihan muqaddimah yang berisi penjelasan awal tentang masalah / materi dan semua hal yang akan dijelaskan pada media pembelajaran interaktif ini dan tombol mulai untuk masuk ke menu utama.

2. Menu Utama berisikan menu - menu yang dapat diggunakan user. Menu - menu tersebut terdiri dari menu Tentang Kami, Belajar Wudhu, Belajar Tayammum, Belajar Shalat, dan Keluar. Dari beberapa menu tersebut user dapat memilih menu mana yang akan digunakan.

3. Menu Tentang Kami berisikan semua hal tentang informasi pembuat program ini. Jika menu ini selesai digunakan maka aka nada pilihan keluar yang prosesnya akan kembali ke Menu Utama.

4. Menu Belajar Wudhu dalam menu ini terdapat beberapa menu yang dapat dipilih user antara lain menu Penjelasan Tentang Wudhu, Tatacara Wudhu, Hal - Hal yang Membatalkan Wudhu, Evaluasi Belajar, Petunjuk Penggunaan dan Keluar. Untuk menu Penjelasan Tentang Wudhu berisikan materi tentang pengertian wudhu, terdapat menu keluar yang akan kembali kepada Menu Belajar Wudhu. Untuk menu Tatacara Wudhu berisikan materi tentang tatacara berwudhu yang dijelaskan step by step, terdapat menu keluar yang akan kembali kepada Menu Belajar Wudhu. Untuk menu Hal - Hal yang Membatalkan Wudhu berisikan materi tentang hal - hal apa saja yang dapat membatalkan wudhu, terdapat menu keluar yang akan kembali kepada Menu Belajar Wudhu. Untuk menu Evaluasi Belajar berisikan soal - soal seputar masalah wudhu yang telah dipelajari, terdapat menu keluar yang akan kembali kepada Menu Belajar Wudhu. Untuk menu Petunjuk Penggunaan berisikan tatacara penggunaan tombol - tombol yang terdapat pada menu - menu Belajar Wudhu, terdapat menu keluar yang akan kembali kepada Menu Belajar Wudhu. Untuk menu Keluar maka akan kembali ke Menu Utama.

5. Menu Belajar Tayammum sama dengan Menu Belajar Wudhu dalam menu ini terdapat beberapa menu yang dapat dipilih user antara lain menu Penjelasan Tentang Tayammum, Tatacara Tayammum, Hal - Hal yang Membatalkan Tayammum, Evaluasi Belajar, Petunjuk Penggunaan dan Keluar. Untuk menu Penjelasan Tentang Tayammum berisikan materi tentang pengertian tayammum, terdapat menu keluar yang akan kembali kepada Menu Belajar Tayammum. Untuk menu Tatacara Tayammum berisikan materi tentang tatacara bertayammum yang dijelaskan step by step, terdapat menu keluar yang akan kembali kepada Menu Belajar Tayammum. Untuk menu Hal - Hal yang Membatalkan Tayammum berisikan materi tentang hal - hal apa saja yang dapat membatalkan tayammum, 
terdapat menu keluar yang akan kembali kepada Menu Belajar Tayammum. Untuk menu Evaluasi Belajar berisikan soal - soal seputar masalah tayammum yang telah dipelajari, terdapat menu keluar yang akan kembali kepada Menu Belajar Tayammum. Untuk menu Petunjuk Penggunaan berisikan tatacara penggunaan tombol - tombol yang terdapat pada menu - menu Belajar Tayammum, terdapat menu keluar yang akan kembali kepada Menu Belajar Tayammum. Untuk menu Keluar maka akan kembali ke Menu Utama.

6. Menu Belajar Shalat sama dengan Menu Belajar Wudhu dan Tayammum dalam menu ini terdapat beberapa menu yang dapat dipilih user antara lain menu Penjelasan Tentang Shalat, Tatacara Shalat, Hal - Hal yang Membatalkan Shalat, Evaluasi Belajar, Petunjuk Penggunaan dan Keluar. Untuk menu Penjelasan Tentang Shalat berisikan materi tentang pengertian shalat, terdapat menu keluar yang akan kembali kepada Menu Belajar Shalat. Untuk menu Tatacara Shalat berisikan materi tentang tatacara shalat yang dijelaskan step by step, terdapat menu keluar yang akan kembali kepada Menu Belajar Shalat. Untuk menu Hal - Hal yang Membatalkan Shalat berisikan materi tentang hal - hal apa saja yang dapat membatalkan shalat, terdapat menu keluar yang akan kembali kepada Menu Belajar Shalat. Untuk menu Evaluasi Belajar berisikan soal - soal seputar masalah shalat yang telah dipelajari, terdapat menu keluar yang akan kembali kepada Menu Belajar Shalat. Untuk menu Petunjuk Penggunaan berisikan tatacara penggunaan tombol tombol yang terdapat pada menu - menu Belajar Shalat, terdapat menu keluar yang akan kembali kepada Menu Belajar Shalat. Untuk menu Keluar maka akan kembali ke Menu Utama.

7. Menu Keluar adalah menu yang digunakan untuk keluar dari program.

\section{HASIL DAN PEMBAHASAN}

\subsection{Tampilan Opening}

Materi - materi yang dibahas pada software ini menggunakan media animasi, gambar, text, dan suara sebagai penjelasannya, untuk interface atau tampilan program menggunakan animasi 2D yang di wakili oleh karakter kartun anak - anak. Berikut ini adalah tampilan Opening dari Program yang dibuat:

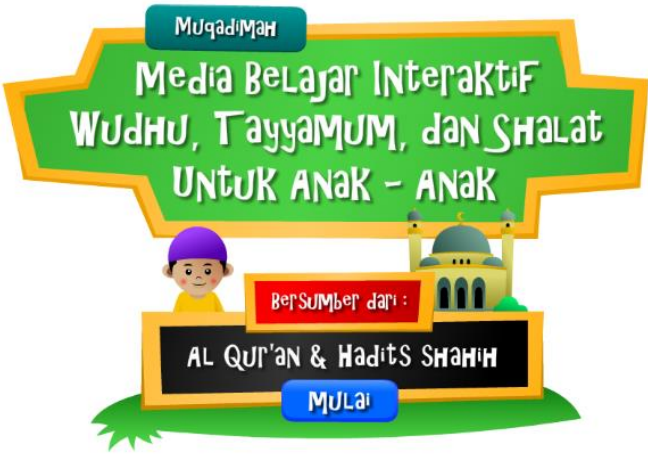

Gambar 2. Tampilan Opening

\subsection{Tampilan Menu Utama}

Tampilan awal dari menu utama berisikan pilihan menu dan tombol antara lain Menu Belajar Wudhu, Menu Belajar Tayammum, Menu Belajar Shalat, Tombol Tentang Program, dan Tombol Exit. Pada masing - masing menu Wudhu, Tayammum, dan Shalat terdapat sub - sub menu yang berhubungan dengan materi yang akan dibahas. Adapun tampilan menu utama sebagai berikut:

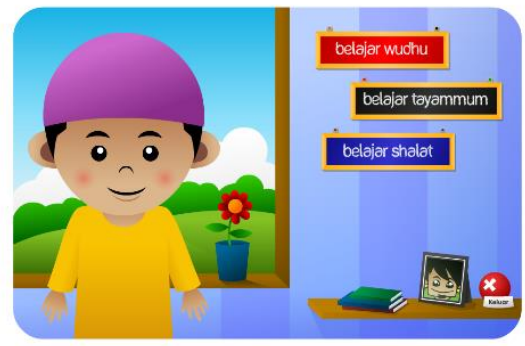

Gambar 3. Menu Utama

\subsection{Tampilan Menu Belajar Wudhu}

Pada Menu Belajar Wudhu terdapat beberapa sub menu antara lain Pengertian Wudhu, Tatacara Wudhu, Pembatal Wudhu, dan Evaluasi Wudhu. Selain itu juga terdapat tombol untuk melihat petunjuk pemakaian dan tombol kembali ke menu utama. Untuk tampilan Menu Belajar Wudhu sebagai berikut:

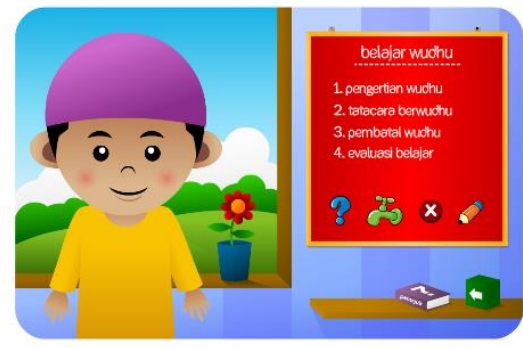

Gambar 4. Menu Belajar Wudhu 


\subsection{Tampilan Menu Belajar Tayammum}

Pada Menu Belajar Tayammum terdapat beberapa sub menu antara lain Pengertian Tayammum, Tatacara Tayammum, Pembatal Tayammum, dan Evaluasi Tayammum. Selain itu juga terdapat tombol untuk melihat petunjuk pemakaian dan tombol kembali ke menu utama. Untuk tampilan Menu Belajar Tayammum sebagai berikut:

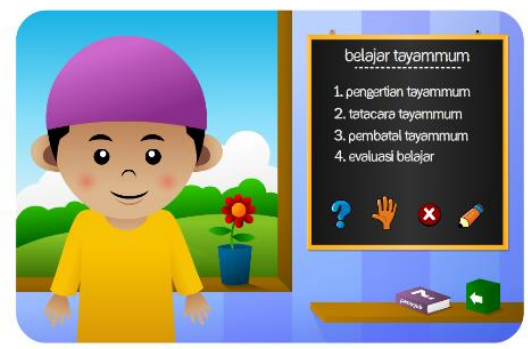

Gambar 5. Menu Belajar Tayammum

\subsection{Tampilan Menu Belajar Shalat}

Pada Menu Belajar Shalat terdapat beberapa sub menu antara lain Pengertian Shalat, Tatacara Shalat, Pembatal Shalat, dan Evaluasi Shalat. Selain itu juga terdapat tombol untuk melihat petunjuk pemakaian dan tombol kembali ke menu utama. Untuk tampilan Menu Belajar Shalat sebagai berikut:

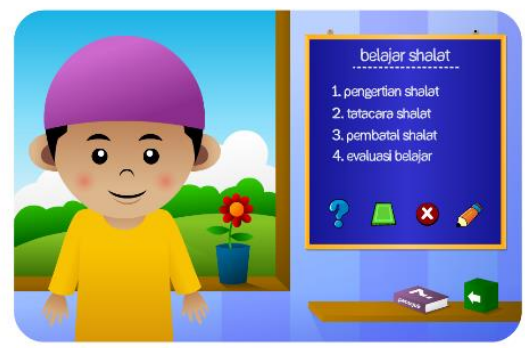

Gambar 6. Menu Belajar Shalat

Tampilan Petunjuk Penggunaan Menu Shalat

Petunjuk penggunaan menu shalat berisikan penjelasan tombol - tombol yang ada pada menu shalat tersebut. Adapun tampilannya sebagai berikut:

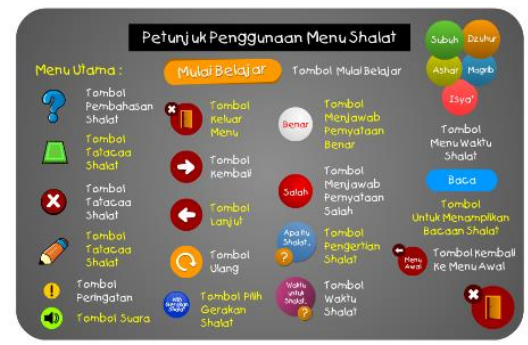

Gambar 7. Tampilan Petunjuk Penggunaan Menu Shalat

\section{KESIMPULAN DAN SARAN}

5.1. Kesimpulan

1. Media pembelajaran interaktif yang berbasis multimedia ini memiliki kelebihan lebih menarik anak-anak karena memiliki gambar yang menarik, teks-teks yang tidak membosankan dan dilengkapi suara, sehingga dapat menjadi salah satu solusi yang efektif yang dapat digunakan untuk media pembelajaran yang lebih efektif dan tidak monoton daripada memakai sistem lama.

2. Dengan adanya sistem pembelajaran interaktif ini, pengguna terutama anak - anak akan lebih termotivasi dalam belajar karena penyampaiannya yang menarik dan lebih mengena di dunia anak - anak.

3. Dengan menggunakan Adobe Flash CS5 sebagai pembuat interface utama terbukti dapat menghasilkan suatu program aplikasi multimedia yang mempunyai tampilan menarik dan dinamis.

\subsection{Saran}

1. Media Pembelajaran Interaktif Sifat Wudhu, Tayammum, Dan Shalat Nabi Shallallahu 'alaihi Wa Sallam Untuk Anak - Anak ini masih adanya kekurangan pada materi ataupun interface menu diharapkan pengembang selanjutnya dapat menambah kekurangan kekurangan yang terdapat pada media pembelajaran interaktif bebrbasis multimedia tersebut.

2. Untuk penggunaan karakter pada media pembelajaran ini hanya menggunakan karakter laki - laki saja, oleh sebab itu diharapkan pengembang selanjutnya dapat menambahkan untuk karakter wanita yang menjadi pilihan karakter sehingga mempermudah pengguna untuk mempelajari materi berdasarkan jenis kelamin masing - masing

\section{DAFTAR PUSTAKA}

[1] Abdullah bin Abdurrahman al-Jibrin, Syaikh. 2010. Tata Cara Wudhu sesuai Dengan Sunnah Rasulullah Fatimah \& Abu Ihsan al-Atsari. Solo: AtTibyan.

[2] Ariani, Niken dan Haryanto, Dany. 2010. Pembelajaran Multimedia di Sekolah, Jakarta: PT. Prestasi Pustakaraya.

[3] Dhanta, Rizky. 2007. Penuntun Lengkap Memakai Adobe FLASH Profesional CS3. Surabaya: Penerbit INDAH Surabaya.

[4] Firmansyah, Dody. 2006. Adobe Audition. Bandung: Pusat Pengembangan Penataran Guru teknologi Bandung (P3GT -TEDC).

[5] Hadi Purnomo, Catur. 2011. Kreasi Objek, Teks, dan Foto dengan CorelDraw, Jakarta: PT. Elex Media Komputindo. 
[6] Hendratman, Hendi. 2010. Tips $n$ Trix Computer Graphics Design, Bandung: Informatika Bandung.

[7] Hidayatullah, P., Akbar, dan Zaky, R. 2011. Animasi Pendidikan Meggunakan Flash, Bandung: Informatika Bandung.

[8] Muhammad Nasiruddin al-Albani, Syaikh. 2010. Sifat Shalat Nabi Sesuai Tuntunan Rasulullah oleh: Abu Ihsan al-Atsari. Solo: At-Tibyan.

[9] Saad Jabal, Nizar. 2011. Ayo Belajar Bersuci. Jakarta: Perisai Qur'an.

[10] Saad Jabal, Nizar. 2012. Ayo Belajar Shalat. Jakarta: Perisai Qur'an.
[11] Suyanto, M. 2003. Multimedia Alat untuk Meningkatkan Keunggulan Bersaing, Yogyakarta: Andi Offset.

[12] Tamim, M. Fayyad. 2010. Buku Panduan Lengkap Ibadah Anak Sholeh. Jakarta: Qultum Media.

[13] McLeod, Jr., Raymod. 2001.Sistem Informasi Manajemen Jilid 1. diterjemahkan oleh: Hendra Teguh. Jakarta: PT Prenhallindo.

[14] Mardiana, Cucu, 4 Januari 2010, Multimedia Pembelajaran dan Aplikasinya, (online),(http://fadacute.wordpress.com, diakses 18 Februari 2013) 